Hermannsson, K. and Lecca, P. (2016) Human capital in economic development: from labour productivity to macroeconomic impact. Economic Papers, 35(1), pp. 24-36. (doi:10.1111/1759-3441.12126)

There may be differences between this version and the published version. You are advised to consult the publisher's version if you wish to cite from it.

This is the peer-reviewed version of the following article:

Hermannsson, K. and Lecca, P. (2016) Human capital in economic development: from labour productivity to macroeconomic impact. Economic Papers, 35(1), pp. 24-36, which has been published in final form at 10.1111/1759-3441.12126. This article may be used for noncommercial purposes in accordance with Wiley Terms and Conditions for Self-Archiving.

http://eprints.gla.ac.uk/114205/

Deposited on: 12 January 2016

Enlighten - Research publications by members of the University of Glasgow http://eprints.gla.ac.uk 


\title{
Human Capital in Economic Development: From Labour Productivity to Macroeconomic Impact
}

\author{
Kristinn Hermannsson ${ }^{a}$ \\ and \\ Patrizio Lecca ${ }^{\mathrm{b}}$
}

\begin{abstract}
a) Robert Owen Centre for Educational Change, School of Education, University of Glasgow, St Andrews Building, 11 Eldon Street, Glasgow G3 6NH, UK. Tel: +44 (0) 141330 2210. kristinn.hermannsson@glasgow.ac.uk

b) Institute for Prospective Technological Studies (IPTS), Joint Research Centre, European Commission. C/ Inca Garcilaso, s/n 41092, Seville, Spain. Tel: +34 95448 8318. patrizio.lecca@,ec.europa.eu
\end{abstract}

\begin{abstract}
Micro-econometric evidence reveals high private returns to education, most prominently in low-income countries. However, it is disputed to what extent this translates into a macro-economic impact. This paper projects the increase in human capital from higher education in Malawi and uses a dynamic applied general equilibrium model to estimate the resulting macroeconomics impact. This is contingent upon endogenous adjustments, in particular how labour productivity affects competitiveness and if this in turn stimulates exports. Choice among labour market assumptions and trade elasticities results in widely different outcomes. Appraisal of such policies should consider not only the impact on human capital stocks, but also adjustments outside the labour market.
\end{abstract}

\section{JEL Codes: O15; O22; E17; I25; F16.}

Keywords: Human Capital; Economic Development; Higher Education; Labour Markets; Trade; Malawi.

\section{Acknowledgements:}

The author's acknowledge the financial support of the Icelandic International Development Agency. The paper has benefitted from the input of seminar participants at Chancellor College, the University of Malawi, and workshops of the Development Studies Association Scotland in Dundee and Edinburgh. Furthermore, we are grateful for the comments of two anonymous reviewers and the editors. The views expressed are the sole responsibility of the authors and not the institutions they are affiliated to. 


\section{Introduction}

A well-known empirical conundrum is that micro and macro impacts of education are not consistent (Pritchet 2001). The earning benefits of education to individuals when aggregated are typically larger than the economy-wide impact found in macro data. This has been flagged up as one of the major gaps in education economics (Psacharopoulos \& Patrinos, 2004) and fostered a degree of scepticism about the macroeconomic contribution of education (Benahabib \& Spiegel 1994, Pritchett 2001). Significant efforts have gone into explaining this via statistical/measurement issues (Hanusheck \& Woessman 2008, Krueger \& Lindahl 2001, McMahon 2000, Schoellman 2012). However, as Sianesi \& van Reenen (2003) point out, less attention has been given to the transmission mechanism from a micro to macro impact. Increasing access to education could be particularly important for low income countries, given the high marginal returns found in labour market data. However, as Chirwa \& Matita (2009) point out, it is often perceived as a luxury in this context. Therefore, it is important both from academic and policy perspectives, to understand under what conditions the individual benefits of education are transformed into an economy-wide impact.

Looking at existing evidence (summarised in the next section) it is clear that signalling effects and measurement issues are insufficient to explain the gap between the individual-level benefit of education and the macroeconomic impact. Therefore we focus on the transmission mechanism from the labour market to the wider economy and the extent to which this is likely to account for the micro-macro mismatch. The analysis is carried out for Malawi, a small country in Sub-Saharan Africa. We draw on comprehensive information on returns to education in selfemployment from the 2004/05 national household survey (Matita \& Chirwa 2009) to calibrate the change in human capital following an increase in the number of higher education graduates in the labour market as a change in effective labour supply ${ }^{1}$. A dynamic applied general equilibrium model is used to simulate endogenous adjustments and the resulting macroeconomic impact ${ }^{2}$. Malawi is a good case study due to the availability of detailed labour market analysis and a 2007 Social Accounting Matrix (SAM) constructed by Douillet et al (2012).

Simulations are carried out under a combination of two common labour market specifications and two sets of parameter estimates for the price sensitivity of exports, as used by the World Bank and the Global Trade Analysis Project (GTAP). Under these assumptions the projected increase in human capital results in widely divergent

\footnotetext{
${ }^{1}$ For simplicity the focus here is on higher education, but the approach can be applied to any stage of the education system.

2 This is similar to the approaches used by Giesecke \& Madden (2006) for Tasmania and Hermannsson et al (2014) for Scotland.
} 
macro impacts. The outcome is driven by the trade mechanism, but exacerbated by the labour market specification. Therefore, we argue that studying labour market issues in isolation is insufficient to determine the development impact of human capital policies, but that analyses need to incorporate the micro-macro transmission mechanism.

The next section summarises previous research. The third section illustrates the projection of the human capital stock. The fourth presents the modelling strategy and macroeconomic data used. The fifth section presents and discusses the results. Brief conclusions are presented in the sixth section. Model details are outlined in appendix.

\section{Wage premia as indicator of labour productivity}

An extensive microeconometric literature documents the rates of return to education at various levels of schooling, in different countries at different times ${ }^{3}$. These studies reveal a clear association between education and wages, typically finding high returns in low income countries (see Psacharopoulous \& Patrinos, 2004, for a survey). For instance, graduates in Malawi earn approximately three times as much as those with primary qualifications (Chirwa \& Matita, 2009, Table 3, p. 12).

Due to an inability to conduct controlled experiments in the field, verifying the causality between education and income is difficult. Interpreted in the spirit of the human capital school (Becker 1964, Mincer 1958, Schultz 1960) education directly increases human capital, which in turn increases the productivity of workers. An alternative view is motivated by the theory of signalling and screening (Arrow 1973, Spence 1973, Stiglitz 1975), which maintains that in extremis education does not enhance human capital (and as a consequence productivity), but simply serves the purpose of revealing innate ability to employers (for an overview see Brown \& Sessions 2004). A range of statistical approaches have been applied to address this conundrum, such as utilising natural experiments (Krueger \& Lindahl 2001, Card 2001) and controlling for fixed effects using twin samples (Bonjour et al 2003, McMahon 2009 Appendix A). The weight of evidence suggests education affects income per se but is not just a proxy for unobserved ability (Blundell et al 2005, Card 1999, 2001, Harmon \& Walker 2003) and that there is a role for signalling, but of modest magnitude relative to overall impacts (Lange \& Topel, 2006). The empirical evidence is mainly from market employment in high income countries. However, drawing on the link between education and output in self-employment can be more representative for low income countries (Joliffe 2004, Soon 1987) and has the added

\footnotetext{
${ }^{3}$ Psacharopoulous \& Patrinos (2004) summarise the results of more than 80 studies of the micro-level returns to education. Card (2001) and Harmon \& Walker (2003) survey the evidence and discuss how it should be interpreted. For an overview of recent work pertaining specifically to Africa see Barouni \& Brocke (2014).
} 
benefit of circumventing the influence of labour market signalling (Heywood \& Wei 2004).

Matita \& Chirwa (2009) analyse the productivity of the self-employed by level of education for several occupations in Malawi, based on the 2004-05 integrated household survey (NSO, 2005). They find higher education to have a varying impact depending on occupation. The least impact is on Maize growers, which are on average $68 \%$ more productive than those with primary qualifications (Table 2, p. 15), while tobacco growers are 136\% more productive (Table 3, p. 16). The biggest impact is for enterprise earnings, where self-employed graduates earn more than 3 times that of those with primary school qualifications (Table 4, p. 18). On average self-employed graduates earn about 2.5 times that of those with primary qualifications. Conversely, for market employment (Chirwa \& Matita, 2009) graduates earn about 3 times that of those with primary qualifications. If the difference between the two estimates is interpreted as a signalling effect this would suggest the wage premia of graduates in market employment, overstates the productivity benefits of higher education by about $20 \%{ }^{4}$.

In a growth accounting exercise, an increase in the education adjusted labour supply would simply mean more inputs into the labour component of the production function, which in turn would suggest more output. The causal mechanism is clear in principle, but rests on strong assumptions. However, macroecometric studies based on cross country regression have provided mixed results on the impact of education and some authors are highly sceptical (Benhabib \& Spiegel 1994). Sianesi \& Van Reenen (2003) survey over 20 macro growth regressions and argue that overall these support the qualitative notion that human capital stimulates growth, but in light of methodological complications they urge caution in quantifying the magnitude of such links.

Even if signalling modifies the individual productivity benefit of education, the direct productivity stimulus as captured in self-employment data is still large. The question remains how does this productivity stimulus translate into a macroeconomic impact and can endogenous adjustments in that process be sufficient to account for the mismatch between empirical observations of micro and macro impacts of education?

\footnotetext{
${ }^{4}$ This is a larger signalling effect than found in high income countries where it is taken to be around $10 \%$. See Hermannsson et al (2014, Section 2.2) for a discussion of the evidence for high income countries.
} 


\section{Human capital projection}

The stock of human capital is calculated following a standard approach from growth accounting, where supply of labour at different skill levels is aggregated into a single stock of human capital, constructed as efficiency units of labour. Following Acemoglu \& Autor (2012), for two types of labour unskilled $(N)$ and skilled $(H)$ the human capital stock in efficiency units can be presented as:

$$
Z=N+\frac{\omega_{H}}{\omega_{N}} H=N+\omega H
$$

where $\omega_{H}$ is the wage of high skill workers, $\omega_{N}$ is the wage of unskilled workers and $\omega=\omega_{H} / \omega_{N}$ is the wage premium of high skill workers.

Figure 1 Projected effective labour supply: \%-change from base year as a result of increases in the share of graduates in the labour market.

Population and human capital stocks are fixed, except for graduates from higher education, which enter the labour market at the rate of graduation exhibited by the higher education system in 2004. Every time period the oldest age cohort of workers retires. This contains a smaller share of tertiary graduates than the new cohorts. Gradually over time the human capital stock (expressed in efficiency units) increases until it reaches a steady state where the number of tertiary graduates entering the labour market equals the number of those retiring. Parameters are informed by the work of Matita \& Chirwa (2009) on the return to education among the selfemployed, discussed in the previous section. The least skilled workers equal one efficiency unit, whereas the wage premium of graduates with tertiary education makes them equivalent to 4.18 efficiency units. This indicates a significant productivity differential between the least skilled and the most skilled. However the base of tertiary skilled workers is very small $(0.4 \%)$ so the overall impact is modest a $0.29 \%$ long run increase in effective labour supply. This process is illustrated in Figure 1.

\section{Modelling approach}

An applied general equilibrium model with forward looking agents is used to estimate the macroeconomic impact that results from the increase in the human capital stock. This is derived from a typical neoclassical, one sector closed-economy model (Abel \& Blanchard (1983), where investment decisions follow a Tobin's q adjustment 
(Tobin, 1969) and are separated from savings decisions. Our Applied General Equilibrium model for Malawi extends this skeletal model. It is solved numerically as an open economy-model, where the Rest of World (ROW) is considered exogenous and trade is price sensitive. The labour market is characterized by imperfect competition where adjustments are obtained through changes in the unemployment rate. Furthermore, it contains a multi-sectoral dimension. It is configured for 18 sectors (see Table A2 in Appendix) and three domestic institutions: households, firms and government. Details of the model are presented in Appendix and model code is available for download ${ }^{5}$. The model is calibrated using s Social Accounting Matrix (SAM) for the year 2007 (Douillett et al, 2012).

The simulation invokes a Harrod neutral productivity change, i.e. an increase in effective labour supply which progresses from $0.007 \%$ in the first period to $0.29 \%$ in the long run, as reported in the previous section ${ }^{6}$. The analysis focusses on two contingencies in the transmission from a micro level increase in human capital to macro level output; the extent to which increased labour productivity affects competitiveness; and the degree to which competitiveness stimulates exports. To this end a comparison is made between the impacts of human capital under two commonly applied labour market assumptions. Firstly we invoke a wage curve (Blanchflower \& Oswald, 1995), where the real wage responds to the local rate of unemployment. This is frequently used for high income countries but empirical work suggests (e.g., Hoddinott, 1996) it is appropriate for low income countries such as Malawi. Second, for comparison we impose a fixed nominal wage. This is a stylised assumption and unlikely to hold in the long-run. However, it can be motivated as an approximation of a situation where labour supply is very flexible, such as when a large share of the population is occupied in subsistence activities, as is the case for many countries in Sub-Saharan Africa. Furthermore, this gives an indication of the sensitivity to labour market conditions, which are an important transmission mechanism from labour productivity to competitiveness. In addition, the model is solved using two alternative parameter estimates for the price sensitivity of exports. The higher elasticity (4) was estimated for the World Bank Linkage model and the lower one (3) for the Global Trade Analysis Project GTAP (Andersson \& Martin, 2006, Table 12A.2, p. 392).

\section{Simulation Results}

Key results from the simulations are presented in Table 1. These are expressed as percentage change from base year values and should be interpreted as showing the

\footnotetext{
${ }^{5}$ http://dx.doi.org/10.5525/gla.researchdata.188

${ }^{6}$ More formally, this occurs as a an increase of the coefficient $\mathrm{A}$ in equation A6
} 
outcome as compared to what would have occurred without the efficiency increase. The first two columns report results obtained under Real Wage Bargaining (RWB), whilst the last two columns show results under Fixed Nominal Wage (FNW). We shall first explain the long-run and short-run results obtained under RWB, before taking a look at the impact of adopting a FNW labour market closure, the time path of adjustment and the influence of varying the trade elasticities.

In a simple growth accounting setup, the change in output can be calculated as the percentage change in labour productivity weighted by the share of labour in base-year GDP ( $47 \%$ in our SAM). In the long run this implies a $0.138 \%$ increase in GDP $(0.47 \times 0.00294=0.00138)$. However, in a general equilibrium framework, the change in output is not only driven by the productivity shock but also by relative changes in the price of output, which in turn affect competitiveness (Adams \& Parmenter 1994, Hermannsson et al. 2014).

Looking at the second column of Table 1 we indeed see that, in the long run, real GDP increases by $0.356 \%$ relative to base year ${ }^{7}$. A significantly larger impact than that implied by growth accounting. Moving down the second column we see that the Consumer Price Index is down by $0.071 \%$ from the base year. This occurs as the increase in labour productivity means more output can be produced with the same level of labour inputs (in natural units), thereby putting downward pressure on commodity prices.

Table 1. Simulation results. Short run (SR) and long run (LR) impacts under Real Wage Bargaining (RWB) and Fixed Nominal Wage (FNW) (\%-change from base year).

This, in-turn, generates an increase in competitiveness which, given the relative price sensitivity of external trade in our model, is translated into an export stimulus amounting to $0.116 \%$ relative to base year. As the downward pressure on prices boosts real income, this encourages household consumption. Similarly, lower prices stimulate investments. Capital stock accumulates with investment until the new steady-state is achieved and results show that the capital stock has grown by $0.416 \%$ relative to base year. This occurs as the investment rate in the model is positively linked to the shadow price of capital. As the Replacement Cost of Capital has fallen $(-0.159 \%)$ additional investment occurs until the return to capital has also been

\footnotetext{
7 The long run is when the capital stock has fully adjusted to the change in productivity. This is reached in period 100 when steady-state conditions are imposed. Capital stock is at its optimum level, with rental rates equal to user cost of capital. In the model the supply of land is fixed in each period. However, we allow economic activities to compete for space through a flexible price of land. Population (identified in the model as working age population) is fixed. However, there is labour mobility among sectors.
} 
reduced to bring about a new steady state. As reported in Figure 2 the efficiency stimulus generates a positive impact in all sectors.

The same principles apply in the short run. However, the situation is more complicated given the forward looking nature of the model, as agents respond to anticipated events and bring forward consumption expenditures. In the general case, as demonstrated by Adams \& Parmenter (1994), short-run impacts of efficiency gains have an ambiguous effect. Although, more output can now be produced for any given level of inputs, it is not clear a priori whether this will lead to increased output or a reduction in the level of inputs, until long-run adjustments restore equilibrium. Hermannsson et al. (2014) analyse such a situation for the case of human capital and indeed find that increased efficiency can lead to a reduction in employment, in the short run.

Figure 2 The long-run output impact on individual sectors under the RWB closure.

In the short-run, which corresponds to the first period of the model, we assume capacity constraints. Therefore capital stock is fixed at its base year values and the initial distribution across sectors is also maintained. As can be seen from column 1 of Table 1, GDP increases slightly with respect to the initial steady-state. In this time frame, the increase in efficiency coincides with an increase in employment reflecting agents' forward looking expectations. ${ }^{8}$. If we were to run the model based on myopic agents, employment would fall in the first period, so that, given fixed labour supply, unemployment would rise putting downward pressure on real wages. However, with perfect foresight agents, we have an anticipated effect according to which unemployment falls by $0.228 \%$ while real wages rise by $0.023 \%$ as reported in Table 1. The short run GDP impact of $0.01 \%$ is still higher than what we would expect in a typical growth accounting set up $(0.47 \times 0.007 \%=0.0035 \%)$. Although exports are falling, increase in output is driven by anticipation effects of the perfect foresight agents ${ }^{9}$.

\footnotetext{
${ }^{8}$ This refers to employment in natural units, whereas the change in employment in efficiency unit is given by the change in natural units plus the change in efficiency. However, labour productivity increases can reduce employment. For a more comprehensive discussion of this point see Adams \& Parmenter (1994).

${ }^{9}$ This is naturally not the case if agents adopt adaptive expectations. The short-run GDP impact when the model is run with myopic expectation equates to $0.0027 \%$ which is, as we would expect, similar and in this case lower than the growth accounting approach. The structure of the myopic model is similar to the forward looking model described in Appendix. The differences are in consumption and investment. In the myopic model, consumption is a linear function of real disposable income and contrary to the perfect foresight case, consumers preserve, in each period, stability between current consumption and wealth. As for Investment, the adjustment rule introduced in the myopic model is such that investments are determined as a fraction of the gap between the desired and actual level of capital stocks adjusted for depreciation.
} 
With fixed nominal wage, workers are not sensitive to the excess demand for labour. In our model the labour market plays an important role in influencing price behaviour. Therefore, the labour market assumption adopted is likely to influence competitiveness effects. The changes in GDP, employment and consumption are greater compared to the case of real wage bargaining in both the short run and the long run. For both labour market closures, the change in employment is greater than the change in GDP in the short-run. This means that the capital/labour ratio falls in this period, whereas in the long-run the capital/labour ratio increases. This occurs as the increase in labour efficiency increases return to capital and investment is stimulated as a consequence.

The short-run impact is greater under fixed nominal wages than real wage bargaining. This is generated by a bigger substitution effect in favour of labour. The real wage falls because workers cannot influence wages, which in turn increases the demand for labour. With a fixed working age population the unemployment rate decreases by $3.7 \%$ from base year values. In the long-run, with total adjustment in capital stock, the nominal wage rigidity provides an additional improvement in competitiveness generated by a bigger fall in prices, which stimulates export demand for local goods. Ultimately, it is the greater increase in exports that drives the stronger long-run impact under the fixed nominal wage.

The results in Table 1 show that competitiveness effects are a key element in realising the macroeconomic impact of human capital. Therefore, it is important to consider the sensitivity of the impact to different estimates of the trade elasticity. Figure 3 reports the period by period percentage change in GDP obtained by performing the same shock described above but varying the trade elasticity. For both labour market closures an increase in the trade elasticity provides a bigger increase in output. However, for the case of fixed nominal wage we observe a dramatic increase in GDP when trade elasticities are higher compared to the case where wage bargaining is adopted.

This suggests that if wages are flexible and depend on the excess demand for labour, the impact of a labour productivity shock is less responsive to change in trade elasticity compared to a situation of wage rigidity. The competitiveness effects, under RWB, are partially offset by an increase in wage income. We should clarify that these results are the consequence of maintaining the labour supply fixed. Indeed, this would not occur if the Malawi economy was able to attract skilled migrants. In this case migration would put downward pressure on wages thus increasing competitiveness effects thereby potentially making the change in economic activity greater under the RWB closure than under the FNW closure. Conversely, the competitiveness effect is conditional on the assumption that labour efficiency is 
improving in Malawi relative to the rest of the World (ROW). If the ROW is experiencing similar increases in productivity, the competitiveness advantages would, of course be muted (but offsetting what would otherwise be a decline in competitiveness).

Figure 3 Comparison of projected GDP changes under alternative assumptions about labour markets and price elasticity of exports $(\%$ change from base year).

\section{Conclusions}

This paper analyses the macroeconomic impact of increasing the skill level of the population in a low income country through higher education. The aim is to provide a simple demonstration of the influence of the transmission mechanism when estimating the macroeconomic impact of an increasing human capital stock. A growth accounting framework, with parameters obtained from previous microeconometric analysis (Matita \& Chirwa, 2009), is used to determine the change in effective labour supply, while a general equilibrium model is used to simulate endogenous adjustments. This reveals that a positive outcome is driven by competitiveness effects boosting exports. A key transmission mechanism is the interaction between labour markets and trade, which makes the overall outcome contingent upon two steps: labour productivity increasing competitiveness and competitiveness stimulating exports.

Interpreting the results from a policy point of view, this suggests that the effectiveness of human capital investment for economic development could be complemented by policies that affect the export elasticity by reducing trade costs, such as through reducing physical and institutional transport barriers (see e.g. Freund \& Rocha 2011, Limão \& Venables 2001). A further analysis of this point would benefit from extending the model to include a more detailed treatment of trade costs, adopting elements from trade-focussed models, such as the model of Malawi by Löfgren (2001).

The results have further bearing in the context of empirical attempts to estimate the macroeconomic impact of education. A priori it is clear that determining the productivity stimulus of human capital precisely is important for the accuracy of the overall analysis. However, there are significant contingencies in the micro-macro transmission mechanism, which are less well understood. The analysis presented here reveals that the macroeconomic outcome of a human capital accumulation progress can be affected by orders of magnitude, depending on how the increase in effective labour supply is transmitted and what endogenous adjustments take place in the rest of the economy. In the simulations presented this variability affects the scale of the 
impact, but it is always positive. This reinforces the interpretation of the empirical evidence that sees a positive macroeconomic impact from increasing the skills of the population (Krueger \& Lindahl 2001, Sianesi \& Van Reenen, 2003) and refutes the notion that there is no impact (Benhabib \& Spiegel 1994, Pritchet 2001).

That said there are still a number of issues to be clarified in the details of the transmission mechanism. Firstly, the magnitude of the competiveness impact is very sensitive to labour market specification. This paper has adopted stylised assumptions, namely that population is fixed and that wages setting can either be described by a wage curve or a fixed nominal wage. Naturally, the labour market is likely to be more responsive in the long run. However, the fixed nominal wage can be motivated as an approximation of a situation where labour supply is very flexible, such as when a large share of the population is occupied in subsistence activities. It would be useful to explore the influence of an internal "migration" from subsistence to market activities explicitly, for example by building on the CGE-modelling of Gelan (2002). Furthermore, the economic impact of graduates is largely driven by increased competitiveness, with subsequent employment and output impacts critically depending on stimulus to exports. In turn, the magnitude of the impact will crucially depends on the labour market conditions. Naturally, in the short-run we might assume nominal wage unchanged however in the long run there is likely to be in operation a more responsive wage setting. An increase in productivity, by and of itself, does not improve competitiveness, unless it is greater than that of trade partners. This is demonstrated for the impact of demographic changes in a multicountry analysis by Mérette \& Georges (2010), but has so far not been taken into account when examining the economic impact of human capital. Secondly, this analysis only pertains to labour supply and does not allow for other supply-side transmission mechanisms, such as social returns and non-market private returns (McMahon, 2000), which are potentially very important. Finally, in order to gauge the per capita impacts of the education system it is important to consider its economic impacts in the context of demographic change. This is particularly important for lowincome countries, such as Malawi, which exhibit fast population growth. Therefore, it is not clear a priori whether production and retention of graduates will keep up with population growth to maintain a constant or growing share of graduates in the work force. Therefore, policy analysis would benefit from a framework that explicitly acknowledges population structure, such as in an Overlapping Generations (OLG) model. 


\section{Appendix: Summary of model}

This appendix elaborates on some of the features of the dynamic applied general equilibrium model used for simulations in this paper. Inevitably due to space constraints the presentation is not exhaustive, but further details of model equations and calibration are available upon request and the model code is available online: http://dx.doi.org/10.5525/gla.researchdata.188

The decision problem of the representative consumer is to choose a sequence of consumption that maximizes the present value of utility, as summarized by the lifetime utility function:

$$
U=\sum_{t=0}^{\infty}\left(\frac{1}{1+\rho}\right)^{t} \frac{C_{t}^{1-\sigma}-1}{1-\sigma}
$$

where $C_{t}$ is the consumption at time period $t, \mathbf{S}$ and $r$ are respectively the constant elasticity of marginal utility and the constant rate of time preference. The dynamic budget constraint ensures that the discounted present value of consumption must not exceed total household wealth, $W$ :

$$
\sum_{t}^{\infty} z(t) P c_{t} C_{t} \leq W_{t}
$$

where $P c$ is the household's aggregate consumption price index and given $r$ the interest rate, $z(t)=\prod_{t}\left(1+r_{t}\right)^{-1}$. Once the optimal path of consumption is obtained from the solution of the intertemporal problem, aggregate consumption is allocated between sectors through a constant elasticity of substitution (CES) function. Household demand for local and imported goods is a result of the intra-temporal cost minimization problem.

The path of investment is obtained by maximizing the present value of the firm's cash flow (Hayashi, 1982) given by profit $\pi_{t}$ less private investment expenditure ${ }^{10}, I_{t}$ subject to the presence of adjustment cost $g\left(x_{t}\right)$ where $x_{t}=I_{t} / K_{t}$ (Devarajan \& Go, 1998):

$$
\begin{gathered}
\sum_{t=0}^{\infty} \frac{1}{(1+r)^{t}}\left[\pi_{t}-I_{t}\left(1+g\left(x_{t}\right)\right)\right] \text { subject to } \\
\dot{K}_{t}=I_{t}-\delta K_{t}
\end{gathered}
$$

\footnotetext{
${ }^{10}$ For simplicity of notation the sector index is omitted. Furthermore, variables not defined over time with the subscript $t$ are assumed to be fixed throughout.
} 
The solution of the dynamic problem gives the shadow price of capital, $\lambda_{t}$ and the time path of investment.

Total gross output $X$, is given by combining value added $(Y)$ and intermediate inputs $(V)$ through Leontief technology:

$$
X_{t}=\min \left\langle\frac{Y_{t}}{a^{Y}} ; \frac{V_{t}}{a^{V}}\right\rangle
$$

where $a^{Y}$ and $a^{V}$ are input coefficients. $Y$ is given by a CES combination of labour $(N)$, private capital $(K)$ and land, $(L)$ :

$$
Y_{t}=\left[a\left(K_{t}\right)^{\vartheta}+b\left(A_{t} N_{t}\right)^{\vartheta}+(1-a-b)\left(L_{t}\right)^{\vartheta}\right]
$$

where $A_{i, t}$ is an index of Harrod neutral technical change and given $y$ the elasticity of substitution $\vartheta=(\psi-1) / \psi$. The demand for labour, capital and land is obtained from first order conditions.

Imported and locally produced intermediate goods are considered imperfect substitutes and are combined under a CES function (Armington, 1969). The demand function for intermediate inputs derives from cost minimization. Each industry produces goods and services that can be exported or sold locally. An export demand function closes the model where foreign demand for Malawi goods $(E)$ depends on the ratio between the ROW price $(P e)$ and the price of output $(P x)$, and the export price elasticity, $h$ :

$$
E_{t}=\bar{E}\left[\frac{P e}{P x_{t}}\right]^{\eta}
$$

Government taxes labour income $\left(\tau^{N} L y\right)$ and capital incomes $\left(\tau^{K} K y\right)$. Its expenditure comprises current spending in goods and services $(G)$, net transfer to households $(T r)$ and interest payment on debt $(r D)$.

$$
\dot{D}=r D_{t}+G_{t}+T r_{t}-\tau^{N} L y-\tau^{K} K y
$$

As this application does not consider changes in natural population, labour force is fixed to the base year. The model is run under two specific labour market closures: real wage bargaining (RWB) and fixed nominal wage (FNW). Under RWB, real wage and unemployment are negatively related as in Blanchflower and Oswald (1995): 


$$
\ln \left[\frac{w_{t}}{c p i_{t}}\right]=c-0.1 \ln \left(u_{t}\right)
$$

where $c$ is a calibrated parameter, $w, c p i$, and $u$ are the nominal wage, the consumer price index and the unemployment rate respectively. In the real wage bargaining regime wages are directly related to workers' bargaining power and respond to excess demand for labour.

The total absorption equation provides equilibrium in the commodity market. This is sufficient to guarantee equilibrium in the payments account since money is not considered as a commodity. In the capital market, capital demand equals the capital stock. Equilibrium in the labour markets is achieved through changes in unemployment rate, as the wage rate is not determined via first order conditions.

Share parameters are obtained from the SAM while some structural and behavioural parameters are based on econometric estimation or best guesses. Some selected benchmark values are reported in Table A1. To solve an infinite time horizon model steady state conditions are imposed at a specific point in time. Hence the transitional pathway is the result of the discrete time solution of the model.

\section{Table A1. Selected benchmark values}

The sectoral classification of the model is reported in Table A2. We have aggregated the 37 sectors SAM as in Douilette, Pauw \& Thurlow (2012) to a more manageable 18 sectors.

Table A.2. Economic activities in the model 


\section{References}

Abel A. B. \& O. Blanchard, (1983). An Intertemporal Model of Saving and Investment, Econometrica, vol. 31, pp. 675-92.

Acemoglu, D. \& Autor, D. (2012). What Does Human Capital Do? A Review of Goldin and Katz's The Race between Education and Technology, Journal of Economic Literature, vol. 50, pp. 426-463.

Adams, P. D., \& Parmenter, B. R. (1994). Microeconomic Reform and Employment in the Short Run, Economic Record, vol. 70, no. 208, pp. 1-11.

Anderson, K., W. Martin \& D. van der Mensbrugghe (2006). Market and Welfare Impacts of Doha Reform Scenarios. In Agricultural Trade Reform and the Doha Development Agenda, K. Anderson and W. Martin eds. London: Palgrave Macmillan, co-published with the World Bank.

Armington, P. (1969). A Theory of Demand for Products Distinguished by Place of Production, IMF Staff Papers, vol. 16, pp. 157-78.

Arrow, K. (1973). Higher Education as a Filter, Journal of Public Economics vol. 2, no. 3, pp. 193-216.

Barouni, M., \& Broecke, S. (2014). The returns to education in Africa: Some new estimates, The Journal of Development Studies, vol. 50, no. 12, pp. 1593-1613.

Becker G S, (1964), Human Capital: A Theoretical and Empirical Analysis, with Special Reference to Education (Chicago: University of Chicago Press).

Benahabib, J. \& Spiegel, M.M. (1994). The role of human capital in economic development Evidence from aggregate cross-country data, Journal of Monetary Economics, vol. 34, pp. 143-173.

Blanchflower G.D. \& A.J. Oswald, (1984). Estimating a Wage Curve for Britain, The Economic Journal, vol. 104, pp. 1025-1043.

Blundell R, Dearden L \& Sianesi B (2005). Evaluating the effect of education on earnings: models, methods and results from the National Child Development Survey, Journal of the Royal Statistical Society A, vol.168, pp. 473-512. 
Bonjour, D., Cherkas, L.F., Haskel, J.E., Hawkes, D.D. \& Spector, T.D. (2003).

Returns to Education: Evidence from UK Twins, The American Economic Review, vol. 93, no. 5, pp. 1799-1812.

Brown, S. \& Sessions, J. (2004). Signalling and Screening. In Geraint, J. \& Johnes. J. (eds.) International Handbook on the Economics of Education. (Cheltenham: Edward Elgar), pp. 58-100.

Card, D. (1999). The Causal Effect of Education on Earnings. In Card, D. \& Ashenfelter, O. (eds.) Handbook of Labor Economics, Volume 3. (Amsterdam: Elsevier), pp. 1801-1863.

Card, D. (2001). Estimating the Return to Schooling: Progress on Some Persistent Econometric Problems, Econometrica, vol. 69, no. 5, pp. 1127-1160.

Chirwa, E.W. \& Matita, M.M. (2009). The Rate of Return on Education in Malawi. University of Malawi, Chancellor College, Department of Economics: Working Paper 2009/01.

Devarajan, A. \& Go, D. (1998). The Simplest Dynamic General-Equilibrium Model of an Open Economy, Journal of Policy Modelling, vol. 20, pp. 677-714.

Douillet, M., Pauw, K., \& Thurlow, J. (2012). A 2007 Social Accounting Matrix for Malawi. Washington DC, USA: International Food Policy Research Institute. Retrieved from the World Wide Web: http://hdl.handle.net/1902.1/18578

Freund, C. \& Rocha, N. (2011). What Constrains Africa's Exports? The World Bank Economic Review, vol. 25, pp. 361-386.

Gelan, A. (2002). Trade liberalisation and urban-rural linkages: a CGE analysis for Ethiopia. Journal of Policy Modeling, vol, 24, no. 7, pp. 707-738.

Giesecke, J. \& Madden, J. (2006). CGE evaluation of a university's effects on a regional economy: an integrated assessment of expenditure and knowledge impacts, Review of Urban \& Regional Development Studies, vol. 18, pp. 229-251.

Hanusheck, E.A. \& Woessmann, L. (2008). The Role of Cognitive Skills in Economic Development, Journal of Economic Literature, vol 46, pp. 607-668.

Harmon C \& Walker I. (2003). The Returns to Education: Microeconomics, Journal of Economic Surveys, vol. 17, pp. 115-153. 
Hayashi F., (1982). Tobin's Marginal q and Average q: A neoclassical Interpretation, Econometrica, vol. 50, pp. 213-224.

Hermannsson, K, Lecca, P., Lisenkova, K., McGregor , P. \& Swales, K. (2014). The Importance of Graduates for the Scottish Economy: A "Micro-to-Macro" Approach, Environment and Planning A, vol. 46, no. 2, pp. 471-487.

Heywood, J. S., \& Wei, X. (2004). Education and signaling: evidence from a highly competitive labor market, Education Economics, vol, 12, no. 1, pp. 1-16.

Hoddinott, J., (1996). Wages and Unemployment in an Urban African Labour Market, Economic Journal, vol 106, pp. 1610-1626.

Jolliffe, D. (2004). The impact of education in rural Ghana: examining household labor allocation and returns on and off the farm, Journal of Development Economics, vol. 73, no. 1, pp. 287-314.

Krueger, A. B. \& Lindahl, M. (2001). Education for Growth: Why and For Whom? Journal of Economic Literature, vol 39, pp. 1101-1136.

Lange, F. \& Topel, R. (2006). The Social Value of Education and Human Capital. In Hanusheck, E. \& Welch, F. (eds.) Handbook of Education Economics (Amsterdam: Elsevier) vol.1, pp. 459-509.

Limão, N. \& Venables, A.J. (2001). Infrastructure, Geographical Disadvantage, Transport Costs, and Trade, The World Bank Economic Review, vol. 15, pp. 451 479 .

Löfgren, H. (2001). A CGE Model for Malawi: Technical Documentation. International Food Policy Research Institute. TMD Discussion Paper no. 70. Retrieved from the World Wide Web: http://www.ifpri.org/sites/default/files/pubs/divs/tmd/dp/papers/tmdp70.pdf

Matita, M.M. \& Chirwa, E.W. (2009). The Impact of Education on SelfEmployment, Farm Activities and Household Incomes in Malawi. University of Malawi, Chancellor College, Department of Economics: Working Paper 2009/02.

McMahon, W. (2000). Education and Development: Measuring the Social Benefits (Oxford: Oxford University Press). 
McMahon, W.W. 2009. Higher Learning, Greater Good: The Private \& Social Benefits of Higher Education (Baltimore: John Hopkins University Press).

Mérette, M. \& Georges, P. (2010). Demographic Changes and the Gains from Globalisation: An Analysis of Ageing, Capital Flows, and International Trade, Global Economy Journal, vol. 10, no.3.

NSO National Statistical Office. (2005). Integrated Household Survey 2004-2005. Zomba: National Statistical Office.

Mincer J, (1958). Investment in Human Capital and Personal Income Distribution. Journal of Political Economy, vol. 66, pp. 281-302.

Pritchet, L. (2001). Where has all the education gone? World Bank Economic Review, vol. 15, pp. 367-391.

Psacharopoulos, G. \& Patrions, H. A. (2004). Human Capital and Rates of Return. In Geraint, J. \& Johnes. J. (eds.) International Handbook on the Economics of Education (Cheltenham: Edward Elgar), pp. 1-57.

Schoellman, T. (2012). Education Quality and Development Accounting, Review of Economics and Statistics, vol. 79, pp. 388-417.

Schultz T W, (1960). Capital Formation by Education, Journal of Political Economy, vol. 68, pp. 571-583.

Sianesi, B. \& Van Reenen, J. (2003). The Returns to Education: Macroeconomics, Journal of Economic Surveys, vol. 17, pp. 157- 200.

Soon, L. Y. (1987). Self-employment vs wage employment: Estimation of earnings functions in LDCs, Economics of Education Review, vol. 6, no. 2, pp. 81-89.

Spence A M, (1973). Job Market Signalling. The Quarterly Journal of Economics, vol. 87 , pp. 355-74.

Stiglitz J E, (1975). The Theory of 'Screening': Education, and the Distribution of Income, American Economic Review, vol. 65, pp. 283-300.

Tobin, J., (1969). A General Equilibrium Approach to Monetary Theory, Journal of Money Credit and Banking, vol. 1, pp. 15-29. 